\title{
Interrelations of plasma calcium, inorganic phosphate, magnesium, and protein over the first week of life
}

\author{
G. J. A. I. SNODGRASS, L. STIMMLER, J. WENT, M. E. ABRAMS, and E. J. WILL \\ From the Departments of Paediatrics, Clinical Biochemistry, and Medicine, \\ Guy's Hospital Medical School, London
}

\begin{abstract}
Snodgrass, G. J. A. I., Stimmler, L., Went, J., Abrams, M. E., and Will, E. J. (1973). Archives of Disease in Childhood, 48, 279. Interrelations of plasma calcium, inorganic phosphate, magnesium, and protein over the first week of life. Plasma levels of calcium, magnesium, phosphate, and protein were measured on the first day of life (cord blood) and at the age of 1 week, in infants fed on breast milk or on one of three cow's milk preparations.

The plasma calcium fell in all patients over the first 24 hours. Breast-fed infants, in all but three instances, showed a rise of calcium in the following 5 to 7 days. There was no mean change in calcium concentration for the other feeds over this period, and about a third of these infants showed a fall: in $9 \%$ to below $7.5 \mathrm{mg} /$ $100 \mathrm{ml}$.

There was a positive correlation between concentrations of calcium and magnesium in the plasma, but an inverse relation between those of calcium and phosphate, at 1 week of age. The concentration of calcium at 1 week of age was related to that of the first day, which in turn was related to that in cord blood. The changes in calcium observed between the age of 1 day and 1 week were inversely related to changes in the plasma phosphate. A direct correlation was also found between changes in calcium and changes in magnesium concentration. All groups of infants showed an increase in plasma phosphate over the first day of life and a further increase by 1 week of age. This rise, however, was significantly smaller in breast-fed infants than in those receiving cow's milk, probably due to the much higher phosphate content of the latter. The hypocalcaemia which occurs at 1 week of life in some infants receiving cow's milk may be due to an inability of the neonatal kidney to dispose of the excessive phosphate loads in these feeds.
\end{abstract}

Convulsions associated with a low plasma calcium concentration were observed in 13 newborn infants over a period of 4 months. All 13 had been fed with an evaporated milk formula at a 1 in 3 dilution. This was the only artificial feed used in the nursery at that time. Examination of the food intake, the rate of weight gain, and the perinatal history failed to reveal a difference between the 13 who convulsed and the large number who did not do so.

The purpose of the present study was two-fold. The first part was a cross-sectional study to establish normal values of plasma calcium, inorganic phosphate, total proteins, and magnesium for infants fed on 4 separate milk feeding regimens. The interrelations of the 4 biochemical measurements

Received 11 August 1972. were also studied. The second aim was to observe the changes which had occurred in these biochemical values for individual patients at different time intervals.

\section{Subjects}

Only gestationally mature infants were included, the minimum acceptable weight for inclusion being arbitrarily taken to be $2500 \mathrm{~g}$. Parental permission was obtained before any infant was taken into the group for study. Sick infants were excluded from the survey. 215 infants were studied and 46 additional cord blood samples were also taken.

\section{Methods}

Feeding. 'Carnation' milk diluted 1 part to 2 parts of water (93 infants), 'Half-Cream Regal' diluted 1 part to 2 parts of water (14), and 'SMA liquid' (40) were 
used in the survey, while there were 68 infants that were breast fed. The infants were given $60 \mathrm{ml} / \mathrm{kg}$ per day over the first 24 hours, $90 \mathrm{mg} / \mathrm{kg}$ per day over the second 24 hours, $120 \mathrm{ml} / \mathrm{kg}$ per day on the third day, and $160 \mathrm{ml} / \mathrm{kg}$ per day on fourth and subsequent days. Mothers were encouraged to breast feed, but where they did not wish to do so the allocation of the feeds was entirely random. The calcium and phosphate contents of the milks are given in Table I.

\section{TABLE I}

Approximate calcium and phosphorus content of milks as offered to the infant

\begin{tabular}{l|c|c|c|c}
\hline & Breast & $\begin{array}{c}\text { 'Carna- } \\
\text { tion' }\end{array}$ & $\begin{array}{c}\text { 'Half- } \\
\text { Cream } \\
\text { Regal' }\end{array}$ & 'SMA' \\
\hline $\begin{array}{c}\text { Calcium } \\
(\mathrm{mg} / 100 \mathrm{ml})\end{array}$ & 33 & 99 & 93 & 56 \\
$\begin{array}{c}\text { Phosphorus } \\
(\mathrm{mg} / 100 \mathrm{ml})\end{array}$ & 16 & 86 & 86 & 44 \\
\hline
\end{tabular}

Sampling. Venous blood was taken from the infants under study between 12 and 36 hours after delivery (designated day 1), or between the 6 th and 8 th days (designated day 6 to 8 ) of life. 97 infants were studied during both periods. The 57 samples of cord blood were obtained by syringe from the placental umbilical vein. All samples were taken into lithium heparin tubes and the plasma separated as soon as possible. The plasma was then deep frozen at $-20^{\circ} \mathrm{C}$ and subsequently analysed in batches twice weekly.

Methods of analysis of plasma. Plasma calcium was estimated by the method of Wieme and Van Raepenbusch (1962), and plasma inorganic phosphate by that described by Natelson (1961), both by Autoanalyser. Total proteins were determined with an Atago Type 1 hand refractometer. Magnesium was measured with a Unicam SP 90 atomic absorption spectrophotometer.

Data processing was performed by transferring the data to punch cards and analysing them using various computer programs on the IBM $360 / 65$ installation at University College, London.

\section{Results}

A large number of results was obtained for the two main sampling periods (day 1 and day 6 to 8 ) and also for cord blood. The total data are considered first. These include both those subjects where only a single sample was taken and those from which at least two samples were taken. Secondly, the changes in individual infants are considered under the heading 'paired data'.

The two groups were further examined for information concerning (1) all samples regardless of feeding schedule; (2) all samples according to sex regardless of feed; (3) samples according to feed; (4) samples according to feed and sex; and (5) correlations between the 4 biochemical parameters under the above 4 conditions.

It was found that no sex differences of statistical significance existed for any of the above conditions. The sexes were therefore combined for all further analyses.

Total data. (i) The mean values for concentrations of calcium, inorganic phosphate, proteins, and magnesium in cord blood plasma are given in Table II for the 57 samples obtained. The only significant correlation found was between magnesium and protein $(\mathrm{r}=0.67 \mathrm{P}<0.01)$.

(ii) Samples on day 1. Table II summarizes the mean results, their SDs and range for each of the 4 feeding regimens, and also for all feeds taken as a single group.

\section{TABLE II}

Levels of plasma calcium, phosphate, magnesium, and proteins for (a) cord blood, (b) infants between 12 and 36 hours of age who were breast fed or fed 'Carnation', 'Half-Cream Regal', or 'SMA', (c) all feeds between 12 and 36 hours

\begin{tabular}{|c|c|c|c|c|}
\hline & $\begin{array}{l}\text { Calcium } \\
(\mathrm{mg} / 100 \\
\mathrm{ml})\end{array}$ & $\begin{array}{c}\text { Phosphate } \\
\text { (mg/100 } \\
\mathrm{ml})\end{array}$ & $\begin{array}{l}\text { Magne- } \\
\text { sium } \\
(\mathrm{mg} / 100 \\
\mathrm{ml})\end{array}$ & $\begin{array}{c}\text { Proteins } \\
(\mathrm{g} / 100 \mathrm{ml})\end{array}$ \\
\hline $\begin{array}{l}\text { Cord blood } \\
\text { Mean } \\
\text { SD } \\
\text { Range } \\
\text { No. }\end{array}$ & $\begin{array}{l}10 \cdot 4 \\
\pm 0 \cdot 62 \\
9 \cdot 1-12 \cdot 1 \\
57\end{array}$ & $\begin{array}{c}5 \cdot 7 \\
\pm 0 \cdot 87 \\
4 \cdot 2-7 \cdot 8 \\
43\end{array}$ & $\begin{array}{c}1 \cdot 72 \\
\pm 0 \cdot 30 \\
1 \cdot 3-2 \cdot 1 \\
19\end{array}$ & $\begin{array}{c}6 \cdot 0 \\
\pm 0 \cdot 72 \\
5 \cdot 0-8 \cdot 2 \\
41\end{array}$ \\
\hline $\begin{array}{l}\text { Breast fed (day 1) } \\
\text { Mean } \\
\text { SD } \\
\text { Range } \\
\text { No. }\end{array}$ & $\begin{array}{l}9 \cdot 0 \\
\pm 0 \cdot 74 \\
7 \cdot 7-11 \cdot 0 \\
43\end{array}$ & $\begin{array}{c}6 \cdot 1 \\
\pm 0 \cdot 77 \\
4 \cdot 4-8 \cdot 4 \\
41\end{array}$ & $\begin{array}{l}1 \cdot 68 \\
\pm 0 \cdot 38 \\
0 \cdot 9-2 \cdot 6 \\
37\end{array}$ & $\begin{array}{l}5 \cdot 9 \\
+0 \cdot 50 \\
5 \cdot 0-6 \cdot 8 \\
36\end{array}$ \\
\hline $\begin{array}{l}\text { 'Carnation' (day 1) } \\
\text { Mean } \\
\text { SD } \\
\text { Range } \\
\text { No. }\end{array}$ & $\begin{array}{l}\quad 8 \cdot 8 \\
\pm 0 \cdot 76 \\
6 \cdot 2-10 \cdot 0 \\
46\end{array}$ & $\begin{array}{c}6 \cdot 5 \\
\pm 1 \cdot 1 \\
4 \cdot 4-8 \cdot 4 \\
43\end{array}$ & $\begin{array}{l}1 \cdot 66 \\
\pm 0 \cdot 31 \\
0 \cdot 9-2 \cdot 1 \\
36\end{array}$ & $\begin{array}{l}5 \cdot 8 \\
\pm 0 \cdot 51 \\
5 \cdot 0-6 \cdot 8 \\
35\end{array}$ \\
\hline $\begin{array}{l}\text { 'Half-Cream } \\
\text { Regal' (day 1) } \\
\text { Mean } \\
\text { SD } \\
\text { Range } \\
\text { No. }\end{array}$ & $\begin{array}{c}8 \cdot 9 \\
0 \cdot 41 \\
8 \cdot 0-9 \cdot 4 \\
14\end{array}$ & $\begin{array}{c}6 \cdot 3 \\
0 \cdot 91 \\
4 \cdot 8-7 \cdot 3 \\
14\end{array}$ & $\begin{array}{c}1 \cdot 85 \\
0 \cdot 17 \\
1 \cdot 5-2 \cdot 2 \\
14\end{array}$ & $\begin{array}{c}5 \cdot 6 \\
0 \cdot 89 \\
4 \cdot 9-6 \cdot 8 \\
13\end{array}$ \\
\hline $\begin{array}{l}\text { 'SMA' (day 1) } \\
\text { Mean } \\
\text { SD } \\
\text { Range } \\
\text { No. }\end{array}$ & $\begin{array}{l}9 \cdot 1 \\
0 \cdot 93 \\
6 \cdot 4-11 \cdot 3 \\
29\end{array}$ & $\begin{array}{c}6 \cdot 3 \\
1 \cdot 18 \\
4 \cdot 1-8 \cdot 3 \\
28\end{array}$ & $\begin{array}{c}1 \cdot 66 \\
0 \cdot 24 \\
1 \cdot 4-2 \cdot 4 \\
17\end{array}$ & $\begin{array}{c}5 \cdot 6 \\
0 \cdot 48 \\
5 \cdot 0-6 \cdot 8 \\
14\end{array}$ \\
\hline $\begin{array}{l}\text { All feeds (day 1) } \\
\text { Mean } \\
\text { SD } \\
\text { No. }\end{array}$ & $\begin{array}{r}8 \cdot 9 \\
0 \cdot 77 \\
132\end{array}$ & $\begin{array}{c}6 \cdot 3 \\
1 \cdot 00 \\
126\end{array}$ & $\begin{array}{r}1 \cdot 69 \\
0 \cdot 31 \\
104\end{array}$ & $\begin{array}{l}5 \cdot 8 \\
0 \cdot 57 \\
98\end{array}$ \\
\hline
\end{tabular}


Mean plasma calcium values were lower than those for cord plasma for all 4 feeds $(P<0.001)$. This difference ranged from 1.2 to $1.5 \mathrm{mg} / 100 \mathrm{ml}$ according to the feed. No significant difference in mean calcium level was found between the 4 feeds at this time.

There was already a mean rise in plasma inorganic phosphate for all feeds. This increase ranged from $0.4 \mathrm{mg} / 100 \mathrm{ml}$ for infants who were breast fed $(P<0.05)$ to $0.8 \mathrm{mg} / 100 \mathrm{ml}$ for infants who were fed 'Carnation' $(P<0 \cdot 001)$. Furthermore, there was a significant difference between the mean inorganic phosphate for infants receiving 'Carnation' and those who were breast fed $(P<0 \cdot 05)$. No such difference was found between 'Carnation' and the remaining 2 feeds.

The mean plasma protein concentrations were very similar for each feed but when combined were significantly lower $(P<0.025)$ than that of cord plasma, with a mean fall of $0.24 \mathrm{~g} / 100 \mathrm{ml}$.

No significant change in magnesium concentrations occurred between cord blood and day 1 and no significant differences existed between feeds.

When all the day 1 samples were considered, regardless of feed, two significant correlations were found. These were between calcium and protein $(r=0.290 \quad P<0.01)$, and negatively between phosphate and calcium $(\mathrm{r}=0.199 \mathrm{P}<0.01)$.

(iii) Samples on day 6 to 8 . Table III summarizes the mean values, SDs, and ranges for all measurements for each feeding regimen. These results are also given for all the feeding regimens combined.

As can be seen, the mean plasma calcium was $0.7 \mathrm{mg} / 100 \mathrm{ml}$ higher for breast-fed infants on day 6 to 8 than on day 1 . This difference was significant $(P<0 \cdot 001)$. No significant changes in mean calcium over this interval were noted for infants fed 'Carnation', 'Half-Cream Regal', or 'SMA'. The mean calcium concentration in breast-fed infants was higher than for the other preparations used $(P<0 \cdot 001)$.

No significant differences were found between calcium values for any of the artificial feeds.

The mean plasma inorganic phosphate concentrations had significantly increased by day 6 to 8 for all feeds. The increases of the mean phosphate values were $0.4 \mathrm{mg} / 100 \mathrm{ml}(\mathrm{P}<0.05)$ for infants who were breast fed, $1.5 \mathrm{mg} / 100 \mathrm{ml}$ for infants fed 'Carnation', $1.6 \mathrm{mg} / 100 \mathrm{ml}(\mathrm{P}<0.001)$ for those fed 'SMA', and $2.4 \mathrm{mg} / 100 \mathrm{ml}$ for those fed 'HalfCream Regal'. There was a difference $(P<0.001)$ between day 6 to 8 phosphate levels of breast-fed infants and of those artificially fed. No difference was found between the artificial milks.
TABLE III

Levels of plasma calcium, phosphate, magnesium, and proteins for infants fed with breast milk and 'Carnation', 'Half-Cream Regal', and 'SMA' milks on day 6 to 8

\begin{tabular}{|c|c|c|c|c|}
\hline Day 6 to 8 & $\begin{array}{c}\text { Calcium } \\
(\mathrm{mg} / 100 \\
\mathrm{ml})\end{array}$ & $\begin{array}{c}\text { Phosphate } \\
\text { (mg/100 } \\
\mathrm{ml})\end{array}$ & $\begin{array}{l}\text { Magne- } \\
\text { sium } \\
(\mathrm{mg} / 100 \\
\mathrm{ml})\end{array}$ & $\begin{array}{c}\text { Protein } \\
(\mathrm{g} / 100 \mathrm{ml})\end{array}$ \\
\hline $\begin{array}{l}\text { Breast fed } \\
\text { Mean } \\
\text { SD } \\
\text { Range } \\
\text { No. }\end{array}$ & $\begin{array}{c}9 \cdot 7 \\
0 \cdot 61 \\
8 \cdot 3-11 \cdot 0 \\
55\end{array}$ & $\begin{array}{c}6 \cdot 4 \\
1 \cdot 19 \\
4 \cdot 5-9 \cdot 1 \\
51\end{array}$ & $\begin{array}{c}1 \cdot 64 \\
0 \cdot 29 \\
0 \cdot 9-2 \cdot 2 \\
39\end{array}$ & $\begin{array}{l}5 \cdot 9 \\
0 \cdot 57 \\
4 \cdot 9-7 \cdot 0 \\
38\end{array}$ \\
\hline $\begin{array}{l}\text { 'Carnation' } \\
\text { Mean } \\
\text { SD } \\
\text { Range } \\
\text { No. }\end{array}$ & $\begin{array}{l}8 \cdot 8 \\
1 \cdot 13 \\
5 \cdot 9-10 \cdot 8 \\
65\end{array}$ & $\begin{array}{l}8 \cdot 0 \\
1 \cdot 19 \\
4 \cdot 6-10 \cdot 2 \\
63\end{array}$ & $\begin{array}{c}1 \cdot 45 \\
0 \cdot 26 \\
0 \cdot 9-2 \cdot 0 \\
54\end{array}$ & $\begin{array}{c}6 \cdot 0 \\
0 \cdot 63 \\
4 \cdot 8-7 \cdot 6 \\
50\end{array}$ \\
\hline $\begin{array}{l}\text { 'Half-Cream } \\
\text { Regal' } \\
\text { Mean } \\
\text { SD } \\
\text { Range } \\
\text { No. }\end{array}$ & $\begin{array}{c}8 \cdot 2 \\
1 \cdot 16 \\
6 \cdot 3-10 \cdot 1 \\
13\end{array}$ & $\begin{array}{l}8 \cdot 7 \\
1 \cdot 40 \\
7 \cdot 0-12 \cdot 0 \\
13\end{array}$ & $\begin{array}{c}1 \cdot 60 \\
0 \cdot 20 \\
1 \cdot 3-2 \cdot 0 \\
12\end{array}$ & $\begin{array}{c}5 \cdot 7 \\
0 \cdot 40 \\
5 \cdot 0-6 \cdot 4 \\
12\end{array}$ \\
\hline $\begin{array}{l}\text { 'SMA' } \\
\text { Mean } \\
\text { SD } \\
\text { Range } \\
\text { No. }\end{array}$ & $\begin{array}{l}9 \cdot 2 \\
0 \cdot 78 \\
7 \cdot 0-10 \cdot 1 \\
30\end{array}$ & $\begin{array}{c}7 \cdot 9 \\
0 \cdot 95 \\
5 \cdot 5-9 \cdot 7 \\
28\end{array}$ & $\begin{array}{c}1 \cdot 63 \\
0 \cdot 27 \\
1 \cdot 2-2 \cdot 3 \\
18\end{array}$ & $\begin{array}{l}5 \cdot 6 \\
0 \cdot 55 \\
4 \cdot 8-6 \cdot 8 \\
18\end{array}$ \\
\hline $\begin{array}{l}\text { All feeds } \\
\quad \text { Mean } \\
\text { SD } \\
\text { Range } \\
\text { No. }\end{array}$ & $\begin{array}{l}9 \cdot 2 \\
\pm 1 \cdot 03 \\
5 \cdot 9-11 \cdot 0 \\
163\end{array}$ & $\begin{array}{l}\quad 7 \cdot 5 \\
\pm 1 \cdot 40 \\
4 \cdot 5-12 \cdot 0 \\
155\end{array}$ & $\begin{array}{l}1 \cdot 5 \\
\pm 0 \cdot 28 \\
0 \cdot 9-2 \cdot 3 \\
128\end{array}$ & $\begin{array}{l}\quad 5 \cdot 9 \\
\pm 0 \cdot 59 \\
4 \cdot 8-7 \cdot 6 \\
118\end{array}$ \\
\hline
\end{tabular}

Mean magnesium levels showed little change between day 1 and day 6 to 8 with the exception of the 'Carnation' group which showed a mean fall ( $P<0.001)$.

Mean protein levels did not change significantly between day 1 and day 6 to 8 for any feeds except 'Carnation', which just achieved a significant rise $(\mathrm{P}<0.05)$.

When the data from all groups were combined for day 6 to 8 there were several significant correlations. The levels of calcium and magnesium were positively correlated $(\mathrm{r}=0.295 \mathrm{P}<0.001)$; the levels of calcium and phosphate were negatively correlated ( $r=0.596 \mathrm{P}<0.001$ ) (Fig. 1); and levels of phosphate and magnesium were also negatively correlated (Fig. 2$)(r=0.373 P<0.001)$. There was no correlation between calcium and protein levels for the data as a whole.

Paired data. (i) Cord samples and day 1. Those patients in whom samples were taken from the cord and on day 1 showed an invariable fall in calcium concentration (Table IV). This fall 


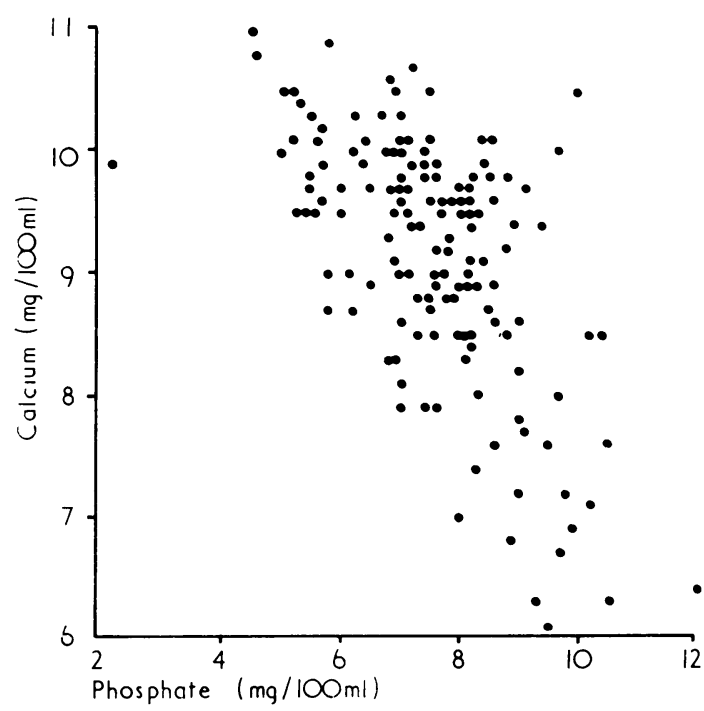

FIG. 1.-Plasma calcium and phosphate levels (all feeds on day 6 to $8(r=-0.596 P<0.001)$.

ranged from 0.3 to $2.4 \mathrm{mg} / 100 \mathrm{ml}$, and the mean fall was $1.6 \pm 0.6 \mathrm{mg} / 100 \mathrm{ml}(\mathrm{SD})$. There was a correlation between calcium levels in cord blood and on day $2(\mathrm{r}=0.80 \mathrm{P}<0.001)$ (Fig. 3).

There was virtually no change in magnesium, protein, or phosphate for the few pairs studied. No correlations were found between these parameters for cord and day 1 samples.

(ii) Day 1 and day 6 to 8 . Of 27 out of 33 infants who were breast fed there was a rise in plasma calcium ranging from 0.1 to $2.2 \mathrm{mg} / 100 \mathrm{ml}$ with a mean of $0.8 \mathrm{mg} / 100 \mathrm{ml}$. 3 infants showed no rise and 3 showed a fall $(2$ of $0.1 \mathrm{mg}$ and 1 of 0.6 $\mathrm{mg} / 100 \mathrm{ml})$.

Infants fed 'Carnation' showed a mean rise in

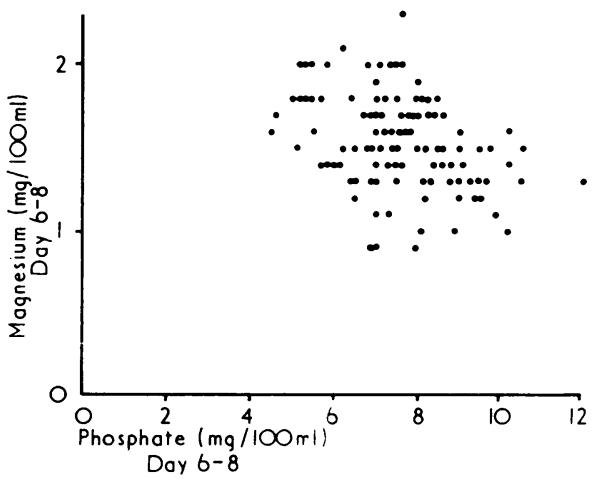

FIG. 2.-Plasma magnesium and phosphate levels (all feeds) on day 6 to $8(r=-0 \cdot 373 P<0.001)$.
TABLE IV

Paired samples showing (a) mean changes and range of changes of the 4 parameters over the first 12 to 36 hours of life, $(b)$ mean changes and range of change of the 4 parameters between day 1 (12 to $36 \mathrm{hr}$ ) and day 6 to 8

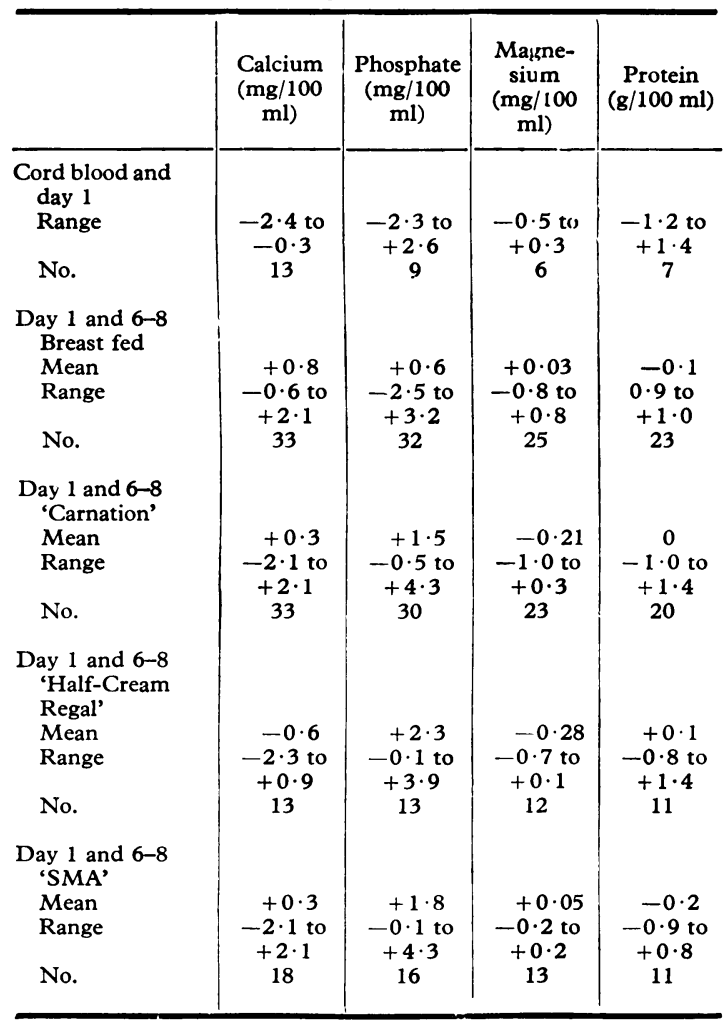

plasma calcium of $0.3 \mathrm{mg} / 100 \mathrm{ml}$ which was less $(P<0.005)$ than the rise found in the breast-fed group. Though 21 out of 33 infants showed a rise in calcium (range 0.1 to $2.1 \mathrm{mg} / 100 \mathrm{ml}$ ), this tended to be of a low order in most cases. A fall occurred in 10 out of 33 infants, and in 5 of these this fall was greater than $1 \mathrm{mg} / 100 \mathrm{ml}$, the maximnm fall being $2 \cdot 1 \mathrm{mg} / 100 \mathrm{ml}$. Of the infants fed 'Half-Cream Regal', only 5 out of 13 showed any rise at all, of which the maximum was $0.9 \mathrm{mg} / 100 \mathrm{ml}$. The remaining 8 showed a fall in calcium of which the maximum was $2.3 \mathrm{mg} / 100$ $\mathrm{ml}$. In the 'Regal' group as a whole there was a mean fall of $0.7 \mathrm{mg} / 100 \mathrm{ml}$, and this was significantly different from the group fed 'Carnation' $(\mathrm{P}<0.005)$.

Infants who were fed 'SMA' showed a mean rise in calcium similar to 'Carnation' $(0.29 \mathrm{mg} / 100$ $\mathrm{ml})$. 


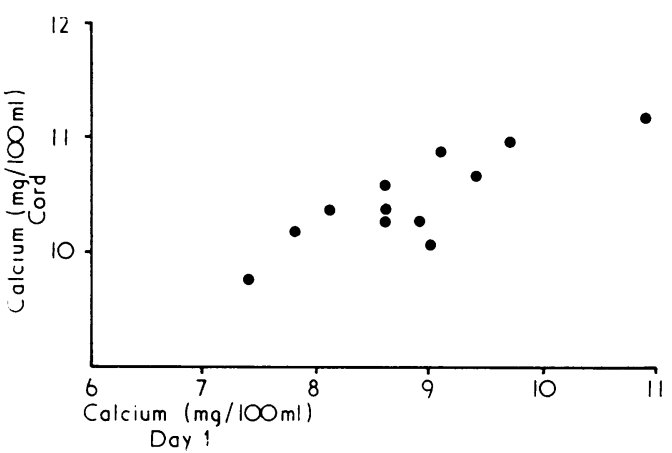

Fig. 3.-Calcium in cord plasma plotted against calcium on day 1. $(r=0.80 P<0.001$.

When all the feeds were considered together there was a positive relation between calcium levels on day 1 and on day 6 to 8 (Fig. 4) (r = 0.35 $P<0 \cdot 001)$.

Mean plasma magnesium levels showed no change in breast-fed infants between day 1 and day 6 to 8 . Though a rise in magnesium of up to 0.8 $\mathrm{mg} / 100 \mathrm{ml}$ was seen in 10 out of 26 infants, a fall was also found in 8 out of 26 of up to $0.8 \mathrm{mg} / 100$ $\mathrm{ml}$. Infants fed 'SMA' showed less scatter of magnesium levels between day 1 and day 6 to 8 , the greatest rise and fall amounting to $0.2 \mathrm{mg} / 100$ $\mathrm{ml}$. In the group fed 'Carnation' there was a mean fall of $0.21 \mathrm{mg} / 100 \mathrm{ml}$ in this period $(P<0 \cdot 01) . \quad 4$ out of 23 showed a fall of up to $1 \cdot 0$ $\mathrm{mg} / 100 \mathrm{ml}$. Of those fed on 'Half-Cream Regal', 11 out of 12 showed a fall of up to $0.7 \mathrm{mg} / 100 \mathrm{ml}$, and only one showed a rise $(0.1 \mathrm{mg} / 100 \mathrm{ml})$.

A highly significant relation was found between magnesium levels on day 1 and those on day 6 to 8 $(\mathbf{r}=0.49 \mathrm{P}<0.001)$ (Fig. 5). A correlation

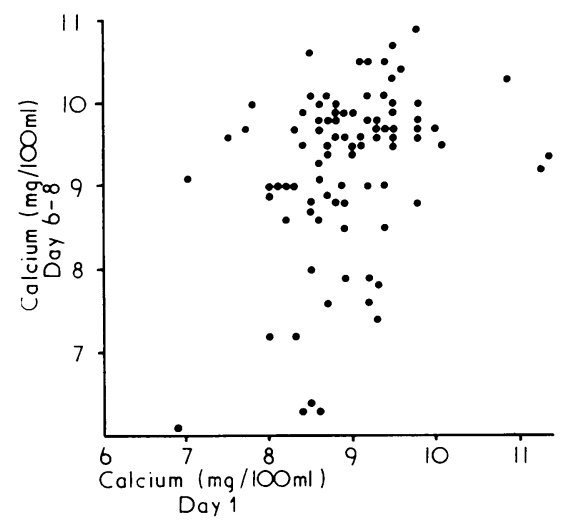

Fig. 4.-Plasma calcium on day 6 to 8 plotted against calcium on day $1(r=0.35 P<0.001)$.

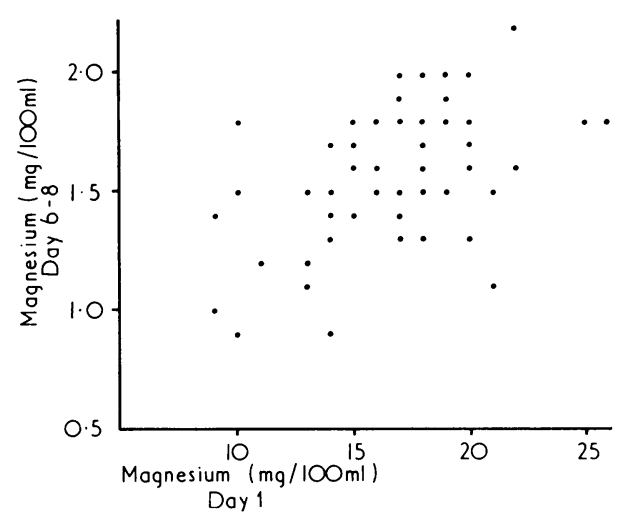

Fig. 5.-Plasma magnesium levels on day 6 to 8 plotted against magnesium levels on day $1(r=0.49 P<0.001)$.

between changes in calcium and changes in magnesium between the 1 st and 6th to 8 th days was also found ( $r=0.39 \mathrm{P}<0.001)$ (Fig. 6).

The mean phosphate level rose in breast-fed infants by $0.6 \mathrm{mg} / 100 \mathrm{ml}$. A rise in level by day 6 to 8 was found in 17 out of 33 infants, with the largest increase being $3.2 \mathrm{mg} / 100 \mathrm{ml}$. A fall was found in 11 out of 33 infants, the greatest being $2.5 \mathrm{mg} / 100 \mathrm{ml}$. For infants fed 'Carnation' a mean increase of $1.5 \mathrm{mg} / 100 \mathrm{ml}$ was found. Only 3 out of 30 infants showed a fall (maximum 0.5 $\mathrm{mg} / 100 \mathrm{ml}$ ), while 24 out of 30 showed a rise (maximum $4.3 \mathrm{mg} / 100 \mathrm{ml}$ ). Even greater mean increases were found for the 'SMA' group ( $1 \cdot 8$ $\mathrm{mg} / 100 \mathrm{ml}$ ) and for the 'Half-Cream Regal' group $(2 \cdot 3 \mathrm{mg} / 100 \mathrm{ml})$. The 'SMA' group showed an increase in 15 out of 16 infants (maximum 3.9 $\mathrm{mg} / 100 \mathrm{ml}$ ) and the 'Half-Cream Regal' group in 12 out of 13 (maximum $6.6 \mathrm{mg} / 100 \mathrm{ml}$ ).

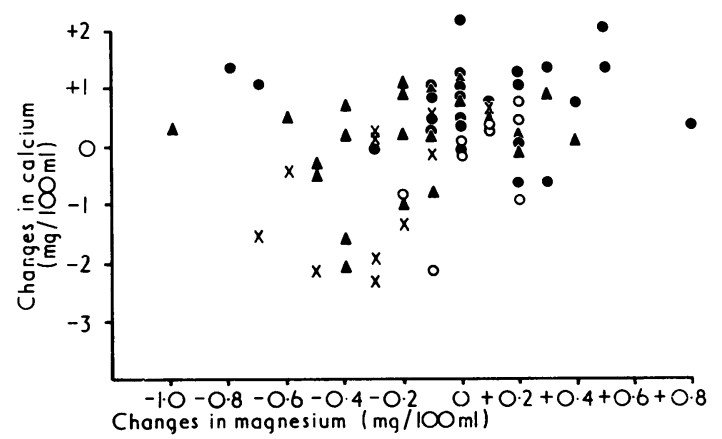

FIG. 6.-Changes in plasma calcium levels between the 1 st and 6th to 8th day plotted against changes in plasma magnesium levels over the same period. , infants fed on breast milk; $\bigcirc$, infants fed on 'SMA' milk; $\Delta$, infants fed on 'Carnation' milk; $\times$, infants fed on 'Half-Cream Regal' milk $(r=0.39 P<0.001)$. 
The increase found in the infants fed breast milk was lower than that found for the other 3 feeds $(P<0 \cdot 0025)$.

There was a negative relation between changes in calcium and phosphate, when all feeding regimens were combined $(\mathrm{r}=0.29 \mathrm{P}<0.01)$.

No correlations were found between changes in phosphate levels and changes in magnesium over this period.

Only small changes in the mean plasma protein values were found and the difference between the regimens was not significant. The scatter of values ranged from $+1.4 \mathrm{~g} / 100 \mathrm{ml}$ maximum, to a low point of $-1 \cdot 2 \mathrm{~g} / 100 \mathrm{ml}$.

\section{Discussion}

As previously reported by Acharya and Payne (1965), the level of calcium in cord blood plasma was higher than at any time over the first week after birth. Published values for calcium in cord blood have ranged from $9.34 \mathrm{mg} / 100 \mathrm{ml}$ (Acharya and Payne, 1965) to $11.5 \mathrm{mg} / 100 \mathrm{ml}$ (Todd, Chuinard, and Wood, 1939). This wide range presumably reflects differences in methodology and sampling. After birth a significant fall of calcium concentration has already occurred by 7 hours (Acharya and Payne, 1965) and reaches a nadir between 12 and 36 hours. In the present study, the mean fall from cord values at 12 to 36 hours was $1.4 \mathrm{mg} / 100 \mathrm{ml}$ as compared with 1.43 $\mathrm{mg} / 100 \mathrm{ml}$ (Bakwin, 1937), $1.34 \mathrm{mg} / 100 \mathrm{ml}$ (Todd et al., 1939), and $1.64 \mathrm{mg} / 100 \mathrm{ml}$ (Acharya and Payne, 1965). The explanation of this rapid fall in total calcium is not certain. It has been shown recently by Khattab and Forfar (1971) that total calcium levels in cord blood are higher than in the mother of the newborn infant at delivery. Radde, Parkinson, and Hoffken (1971), using an ion specific electrode, have shown that this difference is largely due to an increase in ionized calcium values in the infant at delivery as compared with the mother. These authors have suggested the presence of a calcium pump in the trophoblast consisting of an ATP'ase which is sensitive to changes in ionized calcium. They have also shown that the fall in total calcium after delivery is largely due to a fall in ionized calcium which reaches a nadir at about 30 hours of age. Several of the findings in this study indirectly support this finding. Firstly, there was no change in mean plasma protein levels between cord blood and day 1 . Secondly, there was no correlation between calcium levels and protein levels in cord blood, but by day 1 there was a relation between the two parameters. The reason for the precipitate fall in ionized calcium is not known, but it seems possible that it is taken up by bone, as urinary calcium levels are neglible at this time. This process may be facilitated by the increase in $p \mathrm{H}$ occurring soon after birth, and possibly also by a thyrocalcitonin response to the relatively high levels of ionized calcium.

By 1 week of age the plasma calcium level is greater in breast-fed infants than in those fed on the other 3 milks. This confirms the findings of Oppé and Redstone (1968) who also studied various dried milks. We were unable to confirm their findings that there was no significant difference between 'SMA' and breast milk in respect of the mean 6 to 8 day calcium concentration, though the former was higher than either 'Half-Cream Regal' or 'Carnation'. None the less, examination of individual results indicates that calcium levels can be as high in infants receiving cow's milk feeds as those who are breast fed. Where early and late samples were taken, the maximum recorded increase in calcium was identical $(2 \cdot 1 \mathrm{mg} / 100 \mathrm{ml})$ for infants who were breast fed and those who were 'Carnation' fed. The difference between the feeds was, however, most strikingly shown by the number which showed a fall in calcium level by the 6th to 8th day. Only 3 out of 33 breast-fed infants showed such a fall, of which 2 were only $0.1 \mathrm{mg} / 100 \mathrm{ml}$. The lowest calcium found in any breast-fed infant in this study was $8.3 \mathrm{mg} / 100 \mathrm{ml}$. Of 46 infants who received evaporated milks in the paired sample study, 18 showed a fall in calcium by day 6 to 8 (maximum $2 \cdot 3 \mathrm{mg} / 100 \mathrm{ml}$ ). Of these 18 subjects, 4 had levels below $7 \mathrm{mg} / 100 \mathrm{ml}$ and 8 had levels of $7.5 \mathrm{mg} / 100 \mathrm{ml}$ or less, thus placing them at risk of suffering hypocalcaemic tetany (Keen, 1969). 2 patients convulsed during the study and their plasma calcium concentrations were the lowest recorded. When all patients who received 'SMA' were considered (paired and unpaired), it was found that only 4 out of 30 had calcium levels less than $8.5 \mathrm{mg} / 100 \mathrm{ml}(8 \cdot 3,8 \cdot 3$, $7 \cdot 2$, and $7 \cdot 0 \mathrm{mg} / 100 \mathrm{ml}$ ).

Changes in plasma calcium roughly paralleled changes in plasma magnesium. When the changes were studied in individual infants for all feeding regimens combined, a clear correlation was found between changes in magnesium and in calcium levels $(r=0.4 \mathrm{P}<0.001)$.

In spite of the large fluctuations in the changes of calcium observed in different individuals in the paired study, there was still a highly significant relation between levels on day 1 and on day 6 to 8 . Plasma calcium levels at the age of 1 week are therefore not only dependent on the type of feeding but also on the day 1 level, which is in turn related 
to the level in cord blood. This correlation of calcium values on day 1 with those on day 6 to 8 is likely to be largely due to changes in the ionized fraction, as Radde et al. (1971) have shown.

It seems surprising that the milk with by far the lowest calcium content (breast milk) is associated with the highest serum calcium concentrations in the infant, while milks with the highest calcium content ('Carnation' and 'Regal') were associated with the lowest concentrations. It has been suggested (Southgate et al., 1969) that poor absorption of cow's milk fat is responsible for poor calcium absorption, but in the present study the 'Regal' milk which contained only half the fat content of 'Carnation', was if anything associated with greater falls of the plasma calcium. Conversely, Barltrop and Oppé (1970) added butterfat to an experimental milk and showed that this did not result in a lowering of the plasma calcium. In addition, these authors gave a series of 5 milks with differing calcium and phosphate content and showed that there was a positive correlation between plasma calcium and the calcium/phosphorus ratio of the feed. In none of these milks, however, was the calcium content increased to a concentration in excess of that found in a standard dried milk ('Ostermilk No. 1'). The increase in $\mathrm{Ca} / \mathrm{P}$ ratio was achieved by adding calcium to an experimental milk of which both phosphate and calcium content were lower than in standard (dried or evaporated) milks. The differences in calcium levels found by Barltrop and Oppé can equally well be explained in terms of the total phosphate content of each of the milks used in their study. In fact, there is a significant negative correlation obtained from their data between plasma calcium levels and the square of the phosphate concentrations in the feeds which they used. A previous study by Widdowson et al. (1963) showed, using balance techniques, that augmenting the phosphate content of breast milk led to an enhancement of calcium absorption. It seems, therefore, that calcium absorption per se in these infants is not an important factor in determining the plasma concentration of calcium. As the hypocalcaemia is not associated with an increased urinary loss of calcium, it seems possible that it is due to a shift of calcium from the extracellular to the intracellular spaces, or to increased deposit into bone. Hypocalcaemia only occurs within the first two weeks of life, most commonly between the 6 th and 8 th day.

The present findings resurrect the hypothesis that hypocalcaemia is due to an inadequacy of the newborn kidney in eliminating excess phosphate in the plasma (Gardner, 1953). It is suggested that the total phosphate content of a feed is a more important factor in the aetiology of hypocalcaemia than the $\mathrm{Ca} / \mathrm{P}$ ratio, and that transient failure of calcium absorption is unlikely to be a significant contributory factor.

We thank Mr. Armitage for preparing the illustrations, Miss Ruth Perrett for secretarial assistance, and Sister Bishop and the staff of Victoria Ward for invaluable help with this project.

\section{REFERENCES}

Acharya, P. T., and Payne, W. W. (1965). Blood chemistry of normal full-term infants in the first $\mathbf{4 8}$ hours of life. Archives of Disease in Childhood, 40, 430 .

Bakwin, H. (1937). Pathogenesis of tetany of the newborn. American Fournal of Diseases of Children, 54, 1211.

Barltrop, D., and Oppé, T. E. (1970). Dietary factors in neonatal calcium homoeostasis. Lancet, 2, 1333.

Gardner, L. I. (1953). Effect of calcium and phosphate content of the diet of newborn infants. In Calcium and Phosphorus Metabolism. Report of the Fourth $M$ and $R$ Paediatric Research Conference, p. 210. Sponsored by M. \& R. Laboratories, Columbus, Ohio.

Keen, J. H. (1969). Significance of hypocalcaemia in neonatal convulsions. Archives of Disease in Childhood, 44, 356.

Khattab, A. K., and Forfar, J. O. (1971). Interrelationship of calcium phosphorus and glucose levels in the mother and newborn infant. Proceedings of the 13th International Congress of Paediatrics (Wien), 7, 293. Published by the Vienna Academy of Medicine.

Natelson, S. (1961). Techniques of Clinical Chemistry, 2nd ed., p. 576. C. C. Thomas, Springfield, Illinois.

Oppé, T. E., and Redstone, D. (1968). Calcium and phosphorus levels in healthy newborn infants given various types of milk. Lancet, 1, 1045.

Radde, I. C., Parkinson, D. K., and Hoffken, B. (1971). Ionised calcium levels in the healthy and diseased neonate. Proceedings of the 13th International Congress of Paediatrics, (Wien), 7, 363. Published by the Vienna Academy of Medicine.

Southgate, D. A. T., Widdowson, E. M., Smits, B. J., Cooke, W. T., Walker, C. H. M., and Mathers, N. P. (1969). Absorption and excretion of calcium and fat by young infants. Lancet, 1, 487.

Todd, W. R., Chuinard, E. G., and Wood, M. T. (1939). Blood calcium and phosphorus in the newborn. American fournal of Diseases of Children, 57, 1278.

Wieme, R. J., and Van Raepenbusch, F. R. (1962). Automatic determination of calcium in blood and urine using Corinth calcium. Clinica Chimica Acta, 7, 883.

Widdowson, E. M., McCance, R. A., Harrison, G. E., and Sutton, A. (1963). Effect of giving phosphate supplements to breastfed babies on absorption and excretion of calcium, strontium, magnesium, and phosphorus. Lancet, 2, 1250.

Correspondence to Dr. G. J. A. I. Snodgrass, London Hospital, London S.E.1. 